\title{
ТЕХНИКО-ТЕХНОЛОГИЧЕСКИЕ
}

ИННОВАЦИИ

DOI: http://dx.doi.org/10.15688/jvolsu10.2015.1.1

уДК 621.3.049.77

ББК 22.379

\section{THE DEFORMABILITY OF POLYCARBONATE/ POLY(ETHYLENE TEREPHTHALATE) BLENDS}

\section{Mikitaev Muslim Abdulahovich}

Candidate of Chemical Sciences, Senior Researcher,

Department of Organic Chemistry and Macromolecular Compounds, Kabardino-Balkarian State University named after H.M. Berbekov

I_dolbin@mail.ru

Chernyshevskogo St., 175, 360004 Nalchik, Russian Federation

\section{Kozlov Georgiy Vladimirovich}

Senior Researcher, Department of Organic Chemistry and Macromolecular Compounds, Kabardino-Balkarian State University named after H.M. Berbekov

I_dolbin@mail.ru

Chernyshevskogo St., 175, 360004 Nalchik, Russian Federation

\section{Howell Bob A.}

Doctor of Sciences, Professor,

Center for Applications in Polymer Science and Development of Chemistry,

Central Michigan University

Bob.a.howell@cmich.edu

48859 Mount Pleasant, Michigan, United States of America

\section{Zaikov Gennadiy Efremovich}

Doctor of Chemical Sciences, Professor,

Head of Department of Biological and Chemical Physics of Polymers, Institute of Biochemical Physics named after N.M. Emanuel, RAS

chembio@sky.chph.ras.ru

Kosygina St., 4, 119334 Moscow, Russian Federation 


\title{
Mikitaev Abdulah Kasbulatovich
}

\author{
Doctor of Chemical Sciences, Professor, \\ Department of Organic Chemistry and Macromolecular Compounds, \\ Kabardino-Balkarian State University named after H.M. Berbekov \\ I dolbin@mail.ru \\ Chernyshevskogo St., 175, 360004 Nalchik, Russian Federation
}

\begin{abstract}
It has been shown that the extreme enhancement of strain at break for blends polycarbonate/poly(ethylene terephthalate) blends is due to the corresponding structural changes of the indicated blends, which are characterized by their structure fractal dimension variation. The blends deformability rise can be achieved by enhancement of either Flory-Huggins interaction parameter, or shear strength of their autohesional contact. The transparence threshold of macromolecular coils achievement results in sharp reduction of strain at break, i.e. its decrease practically up to zero.
\end{abstract}

Key words: polymer blends, deformability, structure, interaction, fractal dimension.

\section{Introduction}

Polymer blends represent great practical interest, since they allow to obtain novel polymeric materials, not restorting new polymers synthesis. Polycarbonate (PC) and poly(ethylene terephthalate) are used during many years as engineering materials, having many useful properties. PC/PET blends are of great interest and consequently a large amount of their miscibility structure and properties has been fulfilled [6-8; 16] . It was found out [16], that the blends PC/PET with PC large content had two glass transition temperatures, whereas blends rich in PET exhibited only one. Hence, these blends are only partly miscible. The most interesting feature of these blends mechanical behaviour is their deformability maximum within the range of $60-80$ mass. $\%$ PET. The authors [16] have pointed out that physical fundamentals of this effect are unclear. Therefore the purpose of the present work is the study of this important from practical point of view effect with fractal analysis notions usage.

\section{Experimental}

Polycarbonates were used on the basis of bisphenol A of Lexan 131-111 $\left(\bar{M}_{n}=13.300\right.$ and $\left.\bar{M}_{w}=34.200\right)$ provided by General Electric Co. and the poly(ethylene terephthalate) was a bottle grade material (intrinsic viscosity $=0.74 \mathrm{dl} / \mathrm{g}$ ), supplied by Celanese Plastics and Specialties Co., with the commercial designation Petpac 2113 [16].
Pellets of PC and PET were combined in the desired weight ratio and then dried for 1214 hours in an air oven at $353 \mathrm{~K}$ to remove sorbed water. Further the dried pellets were heated to 408 $\mathrm{K}$ to promote crystallization of PET and blended in melt with the usage of screw extruder, having screw diameter of $19 \mathrm{~mm}$ and screw length/diameter ratio of 20 . The extrudate was quenched by passing it through an ice water bath and was chopped into pellets. Then the blends pellets were subjected to injection molding by a ram type machine to form ASTM D-638 dog-bone specimens for mechanical testing. The tension testing was fulfilled on testing machine of Type T5002 of firm Lloyd Instrument Ltd. production at temperature of $293 \mathrm{~K}$ and a cross head speed of $50 \mathrm{~mm} / \mathrm{min}$ [16].

\section{Results and Discussion}

As it is known [14], the most general informator about solids structure is its fractal dimension $d_{f}$, which can be calculated according to the equation [1]:

$$
d_{f}=(d-1)(1+v),
$$

where $d$ is the dimension of Euclidean space, in which a fractal is considered (it is obvious, that in our case $d=3$ ), $v$ is Poisson's ratio, which is determined by the mechanical tests results with the aid of the relationship [10]:

$$
\frac{\sigma_{Y}}{E}=\frac{1-2 v}{6(1+v)},
$$


where $\sigma_{Y}$ and $E$ are yield stress and elastic modulus of polymeric materials, respectively.

Within the frameworks of fractal analysis limiting strain at break $\varepsilon_{f}^{\text {lim }}$ is determined theoretically as follows [11]:

$$
\varepsilon_{f}^{\lim }=C_{\infty}^{D_{c h}-1}-1
$$

where $C_{\infty}$ is characteristic ratio, which is an indicator of polymer chain statistical flexibility [5], $D_{c h}$ is fractal dimension of a chain part between its fixation point, characterizing molecular mobility level [12].

$C_{\infty}$ value is connected with dimension $d_{f}$ by the following relationship [12]:

$$
C_{\infty}=\frac{2 d_{f}}{d(d-1)\left(d-d_{f}\right)}+\frac{4}{3},
$$

and the simplest method of dimension $D_{c h}$ estimation is the empirical formula [12]:

$$
D_{c h}=2.1 d_{f}-3.8 \text {. }
$$

In Fig. 1 the comparison of the obtained experimentally and calculated according to the equation (3) dependences of strain at break $\varepsilon_{f}$ on PET content $C_{\mathrm{PET}}$ in blends PC/PET is adduced. As one can see, well enough both qualitative and quantitative (the average discrepancy of theory and experiment makes up $\sim 15 \%$ ) correspondence of the indicated dependences is obtained.

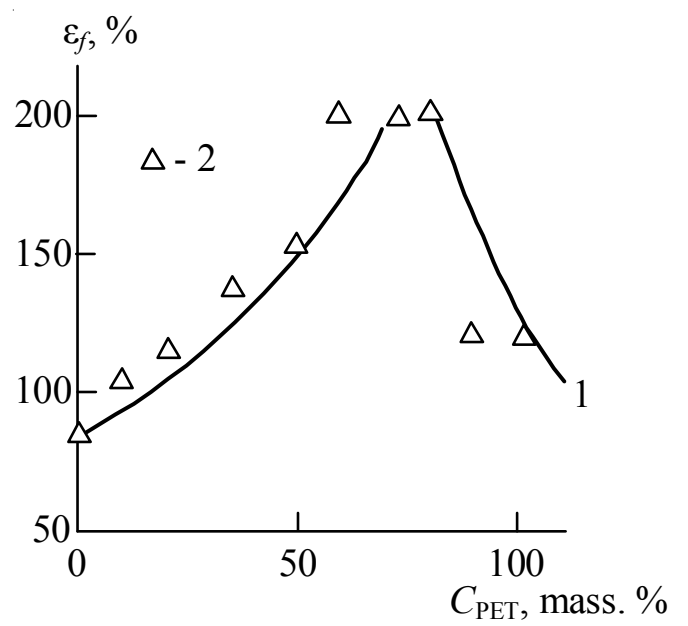

Fig. 1. The calculated according to the equation (3) (1) and obtained experimentally (2) dependences of strain at break $\varepsilon_{f}$ on PET content $C_{\mathrm{PET}}$ in blends $\mathrm{PC} / \mathrm{PET}$
In Fig. 2 the dependence of $\varepsilon_{f}$ on fractal dimension $d_{f}$ for blends PC/PET is adduced. As one can see, good enough linear correlation $\varepsilon_{f}$ $\left(d_{f}\right)$ is obtained, which can be approximated by the following empirical equation:

$$
\varepsilon_{f}=425\left(d_{f}-2.25\right), \%
$$

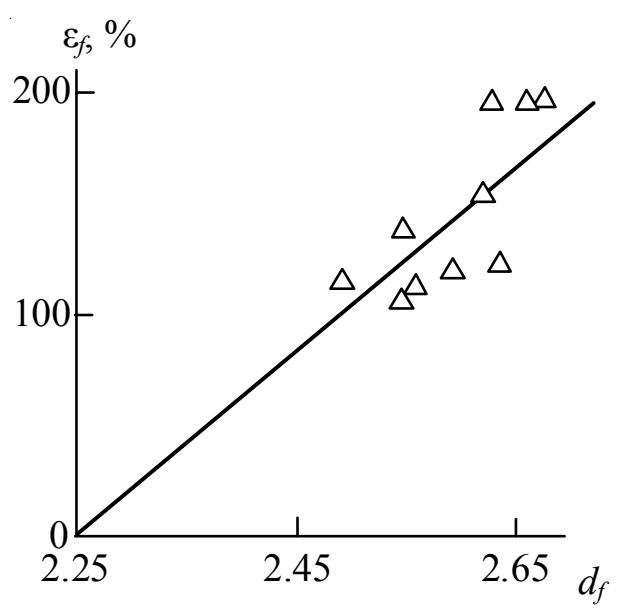

Fig. 2. The dependence of strain at break $\varepsilon_{f}$ on structure fractal dimension $d_{f}$ for blends PC/PET

The equation (6) allows to estimate limiting maximum $\varepsilon_{f}$ magnitude for the considered blends $\mathrm{PC} / \mathrm{PET}$. As it is known [1], the greatest value $d_{f}$ for real solids is equal to 2.95 and in this case maximum value $\varepsilon_{f}$ is equal to $\sim 298 \%$. The linear dependence $\varepsilon_{f}\left(d_{f}\right)$ extrapolation to $\varepsilon_{f}=0$ at $d_{f}=2.25$ is also of interest, the causes of which will be considered below.

There exists a number of specific effects, which should be taken into consideration at their study: components interaction, level of autohesion between them and so on. Interaction between components of the considered blends, i.e. PC and PET, can be described with the aid of FloryHuggins interaction parameter $\chi_{A B}[13]$, which is defined within the framework of fractal analysis with the aid of the equation [9]:

$$
D_{f}=1.50+0.45 \chi_{A B}
$$

where $D_{f}$ is dimension of macromolecular coil, which is estimated for linear polymers according to the formula [9]:

$$
D_{f}=\frac{2 d_{f}}{3} .
$$

In Fig. 3 the dependence of $\varepsilon_{f}$ on FloryHuggins interaction parameter $\chi_{A B}$ is adduced, 
which is approximated well enough by linear correlation and is described analytically by the following empirical equation:

$$
\varepsilon_{f}=275 \chi_{A B}, \% .
$$

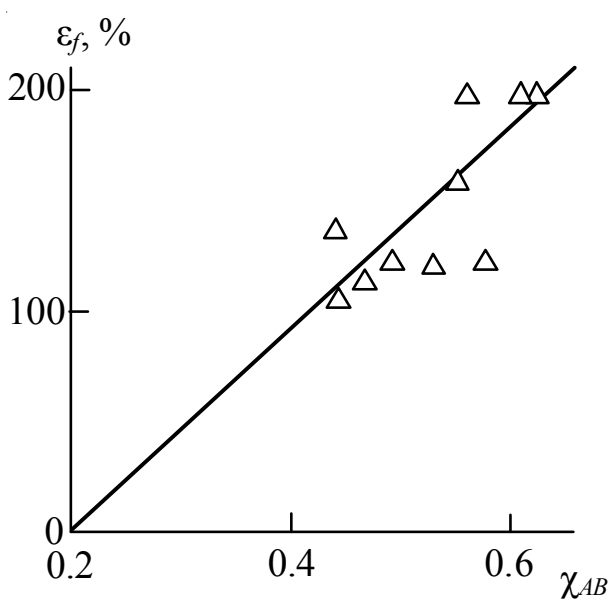

Fig. 3. The dependence of strain at break $\varepsilon_{f}$ on Flory-Huggins interaction parameter $\chi_{A B}$ for blends PC/PET

At the greatest value $D_{f}=1.967$ according to the equation (8) at $d_{f}=2.95$ the value $\chi_{A B}=1.038$ and the greatest value $\varepsilon_{f}=285 \%$, that corresponds well enough to the cited above similar value $\varepsilon_{f}$, which was estimated according to the formula (6).

The level of autohesion between PC/PET blend components can be estimated with the aid of shear strength of autohesional bonding $\tau_{c}$, which is given within the frameworks of generalized fractal model as follows [15]:

$$
\ln \tau_{c}=\left(N_{c}-c\right)-4.4,
$$

where $N_{c}$ is intersections (contacts) of macromolecular coils number in boundary layer of autohesional bonding, $c$ is constant, which is defined according to the equation [15]:

$$
c=16.6\left(D_{f}^{a v}-1.50\right),
$$

where $D_{f}^{a v}$ is average fractal dimension of macromolecular coils.

The value $N_{c}$ can be calculated (in relative units) according to the following relationship [19]:

$$
N_{c} \sim R_{g}^{2 D_{f}-d},
$$

where $R_{g}$ is gyration radius of macromolecular coil, which further at the first approximation is accepted equal to $15 \mathrm{~nm}$.
For the considered PC/PET blends $D_{f}^{a v}=1.73$ and then the equation (10) can be written as follows:

$$
\ln \tau_{c}=R_{g}^{2 D_{f}-3}-8.218
$$

The obtained according to the equation (13) values $\tau_{c}$ vary within the limits of 0.0051 $0.0217 \mathrm{MPa}$, that corresponds to shear strength of autohesional bonding of other polymer pairs [4]. In Fig. 4 the dependence $\varepsilon_{f}\left(\tau_{c}^{1 / 2}\right)$ is adduced (such form of the indicated dependence is chosen with the purpose of its linearization) for the considered blends, which has shown $\varepsilon_{f}$ growth at $\tau_{c}$ increasing, that can be expressed analytically as follows:

$$
\varepsilon_{f}=417 \tau_{c}^{1 / 2}, \% .
$$

Let us note, that the dependence $\varepsilon_{f}\left(\tau_{c}^{1 / 2}\right)$ is extrapolated to $\varepsilon_{f}=0$, i.e. absolutely brittle solid, at $\tau_{c}=0$. This means, that availability of finite nonzero strength of autohesional bonding between blend components is the necessary condition of their nonzero deformability.

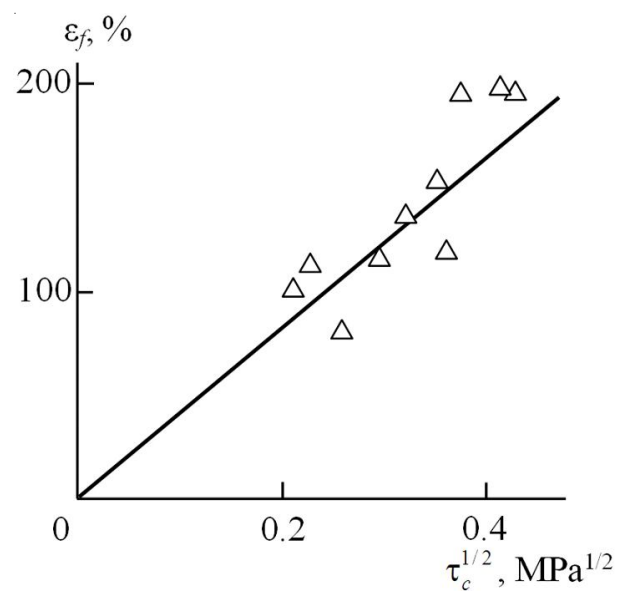

Fig. 4. The dependence of strain at break $\varepsilon_{f}$ on shear strength of components autohesional bonding $\tau_{c}$ for blends PC/PET.

Let us return to the plot of Fig. 2, which gives zero value $\varepsilon_{f}$ at $d_{f}=2.25$. As it follows from the equation (8), the indicated value $d_{f}$ corresponds to the dimension of permeable (transparent) macromolecular coils of $D_{f}=1.50$ [2], i.e. such coils, which can pass freely through one another. This effect reflects the relationship (12) - at $D_{f} \leq 1.50$ the exponent at $R_{g}$ becomes a negative one, that results to $N_{c}$ sharp reduction and according to the equation (13) - to corresponding reduction of shear strength $\tau_{c}$ of autohesional bonding PC-PET. 


\section{Conclusions}

Thus, the present work results have shown that the extreme enhancement of the strain at break for PC/PET blends is due to corresponding structural changes of the indicated blends, which are characterized by their structure fractal dimension variation. The blends deformability rise can be achieved by the enhancement of either Flory-Huggins interaction parameter, or shear strength of their autohesional contact. The transparence threshold of macromolecular coil achievement results in sharp reduction of strain at break, i.e. its decrease practically up to zero value.

\section{Acknowledgements}

The work is performed within the complex project on creation of hi-tech production with the participation of the Russian higher educational institution, the Contract of Tanneta JSC with the Ministry of Education and Science of the Russian Federation ofFebruary 12, 2013 No. 02.G25.31.0008 (Resolution of the Government of the Russian Federation No. 218).

\section{REFERENCES}

1. Balankin A.S. Synergetics of Deformable Body. Moscow, Publishing Ministry of Defence SSSR, 1991.404 p. (in Russian).

2. Baranov V.G., Frenkel S.Ya., Brestkin Yu.V. Mernost razlichnykh sostoyaniy lineynoy makromolekuly [The Dimensionality of the Different States of Linear Macromolecules]. Doklady AN SSSR, 1986, vol. 290, no. 2, pp. 369-377. (in Russian).

3. Baron A.A., Bakhracheva Yu.S., Osipenko A.P. Fracture Toughness Estimation by Means of Indentation Test. Mekhanika, 2007, vol. 67, no. 5, pp. 33-36.

4. Boiko Yu.M., Prudhomme R.E. Strength Development at the Interface of Amorphous Polymers and Their Miscible Blends, Below the Glass Transition Temperature. Macromolecules, 1998, vol. 31, no. 19, pp. 6620-6626.

5. Budtov V.P. Physical Chemistry of Polymer Solutions. Saint Petersburg, Khimiya Publ., 1992. 384 p.
6. Chen X.-Y., BirleyA.W. Thermal Property and Miscibility of Polycarbonate/Copolyester Blends. British Polymer Journal, 1985, vol. 17, pp. 347-353.

7. Hanrahan B.D., Angell S.R., Runt J. Miscibility and Melting in Poly(Butylene Terephthalate)/ Poly(Bisphenol A-Carbonate) Blends. Polymer Bulletin, 1985, vol. 14, pp. 399-406.

8. Hobbs S.Y., Groshans V.L., Dekkers M.E.J.Effect of Interfacial Forces on Polymer Blend Morphologies. Polymer Bulletin, 1987, vol. 17, pp. 335-339.

9. Kozlov G.V., Dolbin I.V., Zaikov G.E. The Fractal Physical Chemistry of Polymer Solutions and Melts. Toronto, New Jersey, Apple Academic Press, 2014.316 p.

10. Kozlov G.V., Sanditov D.S. Anharmonic Effects and Physical-Mechanical Properties of Polymers. Novosibirsk, Nauka Publ., 1994. 261 p. (in Russian).

11. Kozlov G.V., Yanovskiy Yu.G. Fractal Mechanics of Polymers. Chemistry and Physics of Complex Polymeric Materials. Toronto, New Jersey, Apple Academic Press, 2015.370 p.

12. Kozlov G.V., Zaikov G.E. Structure of the Polymer Amorphous State. Leiden, Brill Academic Publishers, 2004. $465 \mathrm{p}$.

13. Krause S. Polymer Blends. In 3 vols. Vol. 1. London, Academic Press, 1978. 144 p.

14. Kuzeev I.R., Samigullin G.Kh., Kulikov D.V., Zakirnichnaya M.M. Complex Systems in Nature and Engineering. Ufa, USSTU Publ., 1997. 225 p. (in Russian).

15. Magomedov G.M., Yakhyaeva Kh.Sh., Kozlov G.V., Stoyanov O.V., Deberdeev P.Ya., Zaikov G.E. Theoretical Fractal Model of Autogenie Amorphous Polymers. Herald of Kazan Technological University, 2014, vol. 17, no. 2, pp. 30-33.

16. Murff S.R., Barlow J.W., Paul D.R. Positron Annihilation Study on PP/EPDM Polymer Blend. Journal of Applied Polymer Science, 1984, vol. 29, pp. 3231-3240.

17. Shapochkin V.I., Semenova L.M., Bakhracheva Yu.S., Gyulikhandanov E.L., Semenov S.V. Effect of Nitrogen Content on the Structure and Properties of Nitrocarburized Steel. Metal Science and Heat Treatment, 2011, vol. 52, no. 9-10, pp. 413-419.

18. Vasilyev A., Deynichenko E., Popov D. Internal Combustion Engine Valve Gear Cam Wear and Its Influence on Valve Gear and Engine Efficiency. Mekhanika, 2005, vol. 54, no. 4, pp. 44-49.

19. Vilgis T.A. Physics. Toronto, New Jersey, Apple Academic Press, 1988. 354 p. 


\title{
ДЕФОРМИРУЕМОСТЬ МАТЕРИАЛОВ НА ОСНОВЕ СМЕСИ ПОЛИКАРБОНАТ/ПОЛИ(ЭТИЛЕН ТЕРЕФТАЛАТА)
}

\author{
Микитаев Муслим Абдулахович
}

Кандидат химических наук, старший научный сотрудник кафедры органической химии и высокомолекулярных соединений, Кабардино-Балкарский государственный университет им. Бербекова I_dolbin@mail.ru ул. Чернышевского, 175, 360004 г. Нальчик, Российская Федерация

\section{Козлов Георгий Владимирович}

Старший научный сотрудник кафедры органической химии и высокомолекулярных соединений, Кабардино-Балкарский государственный университет им. Бербекова I dolbin@mail.ru ул. Чернышевского, 175, 360004 г. Нальчик, Российская Федерация

\section{Хоуэлл Боб А.}

Доктор наук, профессор,

Центр развития полимерной науки и химии,

Центральный Мичиганский университет

Bob.a.howell@cmich.edu

48859 г. Маунт Плезант, Мичиган, Соединенные Штаты Америки

\section{Заиков Геннадий Ефремович}

Доктор химических наук, профессор,

заведующий отделом биологической и химической физики полимеров, Институт биохимической физики им. Н.М. Эмануэля РАН chembio@sky.chph.ras.ru ул. Косыгина, 4,119334 г. Москва, Российская Федерация

\section{Микитаев Абдулах Касбулатович}

Доктор химических наук, профессор кафедры органической химии и высокомолекулярных соединений, Кабардино-Балкарский государственный университет им. Бербекова I_dolbin@mail.ru ул. Чернышевского, 175, 360004 г. Нальчик, Российская Федерация

Аннотация. В статье показано, что наблюдается экстремальное повышение относительного удлинения при разрыве для материала, произведенного на основе смеси поликарбонат/поли(этилен терефталата), которое вызвано соответствующими структурными изменениями указанных смесей, отличающихся своей структурой фрактальной размерности. Повышение деформируемости указанной смеси может быть достигнуто либо путем повышения параметра взаимодействия Флори-Хаггинса, либо прочностью на сдвиг их контактов.

Ключевые слова: полимерные смеси, деформируемость, структура, взаимодействие, фрактальная размерность. 